LUCYNA SZANIAWSKA

Polish Academy of Sciences, Institute of the History of Science

Team for the History of Cartography

Warsaw, Poland

lucyna-szaniawska@wp.pl

\title{
Lithological maps visualizing the achievements of geological sciences in the first half of the 19th century
}

\begin{abstract}
The paper discusses selected maps of rock strata which exemplify the evolution stages of presentation methods of cartographic data concerning the geological structure of selected countries (France, Great Britain and Germany) which in the first half of the nineteenth century constituted the leaders of the field. The results of geologists' work are used to present the content of maps, provide explanations and showcase the methods and techniques chosen by the maps' creators. The analysed maps are accompanied by geological writings which contain descriptions of the chronological order within rock formations and strata defined on the basis of fossils, methods of recreating the geological history of individual regions, and attempts of compiling the acquired knowledge and using it to describe larger areas. The author discusses also two maps of Europe published in the mid-nineteenth century, which are the result of cooperation and research achievements of geologists from different countries.
\end{abstract}

Keywords: history of cartography, geological cartography, lithological maps

\section{Introduction}

In the second half of the eighteenth century, thanks to the development of the search for mineral resources, topographic surveys and geological studies, the number of symbols used on mineralogical maps reached the level of forty, see e.g. Carte minéralogique où l'on voit la nature et la situation des terreins qui traversent la France et l'Angleterre... created by Jean-Etienn Guettard in 1764 (45 symbols of minerals and rocks in the shapes of circles, rectangles, rhombuses, crosses, etc.). Later, other authors, e.g. Johann F.W. von Charpentier on his 1778 map titled Petrographische Karte des Churfürstenthums Sachsen und der Incorporirten Lande and Johann Jirasek on the 1791 map, Petrographische Charte eines Theils des Böhmischen Riesengebirges an der Schlesischen Gränze, increased the number of symbols even further by manually colouring the areas covered by certain rock formations, such as granites, gneisses, shists and limestones.

Already at that time, the mineralogical maps were accompanied by writings resembling scientific dissertations, but they contained mainly general information about landscape, whereas detailed information about minerals was rarely provided.

\section{Theoretical foundations of lithological maps at the end of the 18th century}

The first writings which contained mainly descriptions and theories concerning creation and transformation of rock formations, which formed the so-called "fundaments of modern geology", and were accompanied by graphic boards and maps (A.J. Wójcik 2012, p. 177) started to appear at the end of the 18th century. Their first creators were French, German and British scientists, e.g. Johann Gottlob Lehmann who was initially involved in the exploration of various deposits, including metal deposits in Saxony. In his 1756 work Versuch einer Geschichte von Flötz-Gebürgen, he discussed the sequences of sedimentary rocks, creating their lithological classification, and drew the first geological cross-sections (C.W. Gümbel 1883, pp. 140-141). Georg Christian Füchsel in 
Thuringia used the Lehmann classification to describe the sedimentary rock strata in his Historia Terrae et Maris ex Historia Thuringiae, per montium descriptionem erecta published in Erfurt in 1761, and developed the first geological map of the Thuringian mountains (G. Gohau 1990, pp. 101-102; W. Hacker 2009, p. 67). The French geologist Nicolas Desmarest, who studied basalt rocks, described the geological landscape of the Monts Dore massif ${ }^{1}$ in Auvergne, which had been shaped by past volcanic eruptions, in an article published in 1771 by Académie Royale des Sciences in Paris Memoire sur l'origine \& la nature du Basalte à grandes colonnes polygones, déterminées parl'Histoire Naturelle de cette pierre, observée an Auvergne (W. Gohau 1990, pp. 108-109). He presented the results of his observations on the map included in the article Carte d'une partie de l'Auvergne où sont figurés les Courants de Laves dans lesquels se trouve le Basalte en Prismes, en Boules \&c.... (fig. 1) (D. Oldroyd 2013, pp. 50, 53; A.J. Wójcik 2012, pp. 176-177).

Abraham Gottlob Werner, a professor of geology at the Mining Academy in Freiberg, was the first scientist who developed a mineral classification system, which he published with a guide allowing for the identification of minerals entitled Von den äußerlichen Kennzeichen der Foßilien in Leipzig in 1774 . He described a set of external features which could be used to identify rocks and minerals, such as their colour, gloss, shape, transparency level, fragrance, hardness, specific weight, etc. Then in the study titled Kurze Klallifikation und Belchreibung der verlchiedenen Gebirgsarten, which he published in Dresden in 1787, he described the division of rocks which make up rock masses into four major classes: (1) primary rocks ${ }^{2}$ (Uranfängliche), (2) stratified rocks (Flötze), (3) volcanic rocks (Volkanische) and (4) alluvial rocks (Angeschwemmte) (A. G. Werner, 1787, p. 11). Later, in 1791, he added one more class - transitional rocks (Übergangsgebirge) - sedimentary rocks from late Palaeozoic Era located on a layer of eruptive or metamorphic rocks (A.G. Werner 1791). He distinguished between twelve Alter Rother Sandstein formations created during the period which is now known as the Devonian.

\footnotetext{
1 The map included the inscription "Monts Dorles".

2 According to Z. Wójcik (1990, p. 102) - primordial.
}

The ceiling consisted of a series of Lower Permian limestones with Zechstein salt-bearing deposits, etc. (G. Gohau 1990, pp. 102-105). The so-developed system and its application in field research were of fundamental importance in the development of geological maps and arranging explanations in their legends.

Scottish geologist James Hutton, who was both Werner's adversary and a continuator of his work, formulated theories suggested that geological processes (such as erosion and sedimentation) are permanent, natural and occur in geological time (both in the past and in the present - uniformitarianism). He announced his theories for the first time on 4 July 1785 at the meeting of the Royal Society of Edinburgh, and published them in 1788 in the first volume of the journal "Transactions of the Royal Society of Edinburgh" (J. Hutton 1788). The final written version of Hutton's theories appeared in 1795 in the two-volume book titled Theory of the Earth. It contained four sheets, two of which depicted the layered arrangement of rock formations: vertical rock strata with horizontal overburden and folded strata (J. Hutton 1795).

John Playfair, a Scottish geologist and a proponent of J. Hutton's theories, defended them against the accusations raised by their contemporaries. He expanded upon the concepts proposed by Hutton in a book published in 1802 (several years after the death of Hutton) titled Illustrations of the Huttonian Theory of the Earth. He explained the theory of uniformitarianism in a coherent manner and did the same for many geological processes, such as erosion, hydrothermal processes in rock formation and others, supplementing all of this with the results of his own observations of different types of rock strata (J. Playfair 1802). J. Playfair's arguments were persuasive - he popularised Hutton's geological theories and had a fundamental impact on the content of geological maps created in the first twenty years of the 19th century.

\section{The first lithological maps at the turn of the 18th and 19th centuries as exemplified by the maps created by William G. Maton and Robert Fraser}

The theories formulated by the end of the 18th century, which explained geological processes and construction of rock formations, reached a level sufficient for the development 

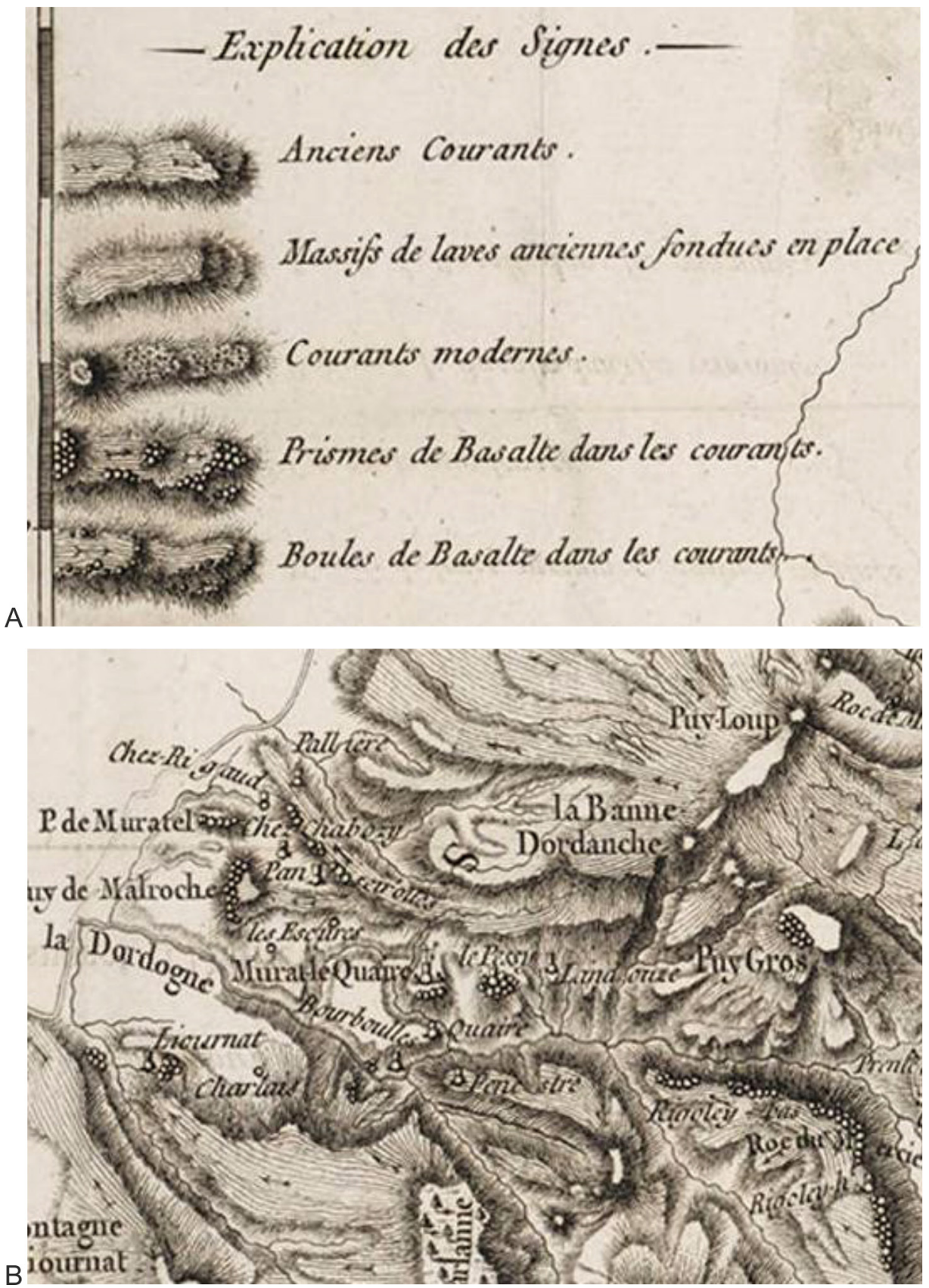

Fig. 1. The explanation - A, and a part - B of the map titled Carte d'une partie de l'Auvergne, created by Nicolas Desmarest at a scale of approx. 1:130,000; the explanation contains five categories:

(1) directions of lava flows, (2) former lava fields, (3) directions of later lava flows, (4) basalt columns together with their flow directions, (5) basalt pillows together with their flow directions (from the collection of Bibliothèque nationale de France) 
of "modern" geological maps - the lithological maps. Naturally, when the rules of an emerging scientific field are being defined, the activities of scientists are always multidirectional - the authors use different kinds of research, as well as descriptive and graphic methods.
Picturesque Scenery, and Antiquities, of the Western Counties of England, Made in the Years 1794 and 1796: Illustrated by a Mineralogical Map, and Sixteen Views in Aquatinta by Alken was published in two volumes in 1797 (J.D. Mather 2016). Included in the second vo-
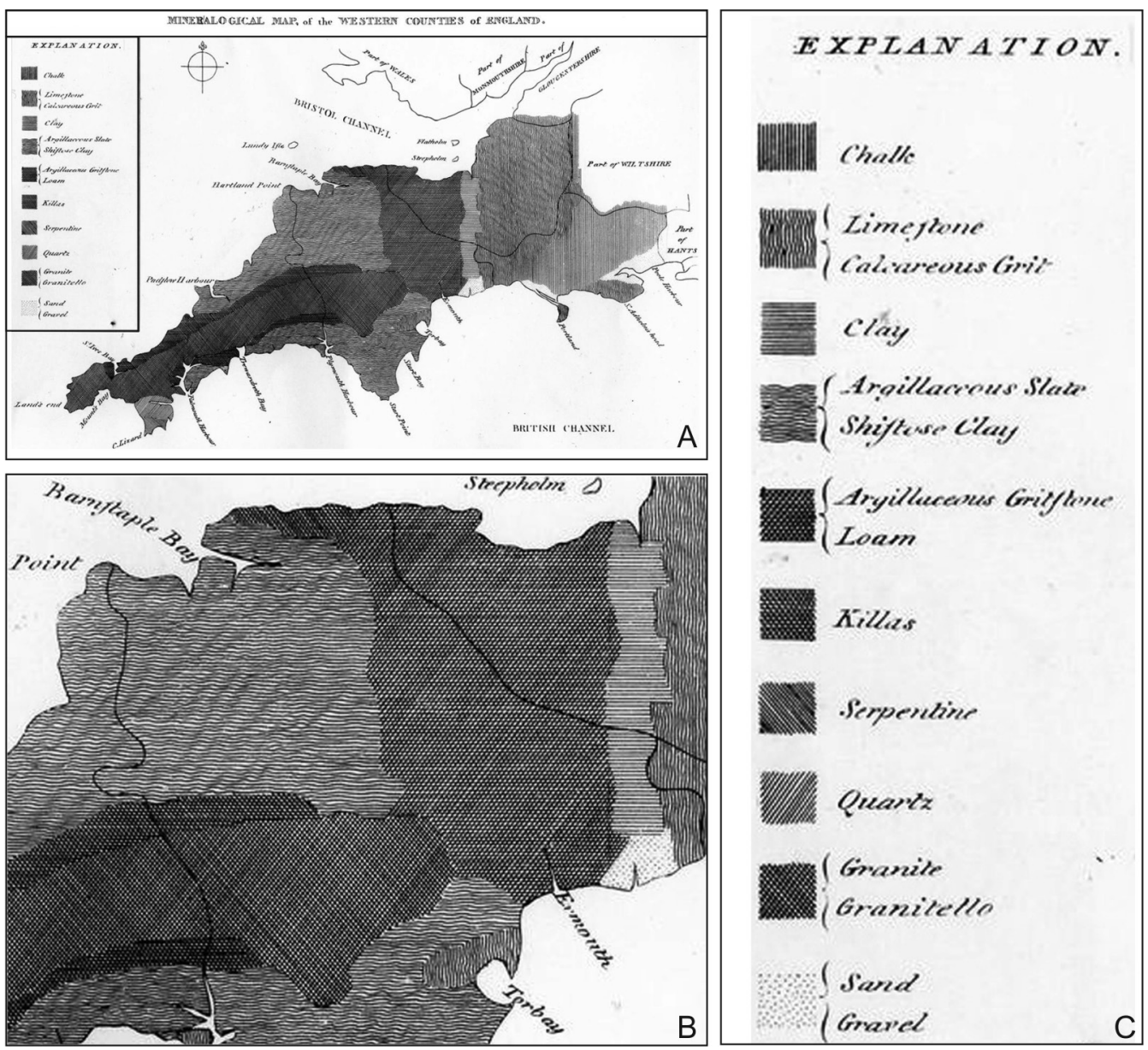

Fig. 2. Mineralogical Map of the Western Counties of England, published by W.G. Maton in $1797-\mathrm{A}$, the middle part - B and its explanation - $\mathrm{C}$ (from the collection of the Princeton University)

A study summarising the results of geological field research conducted by William Georg Maton in 1794-1796 in Somerset, Dorset, Devon and Cornwall counties of south-west England, was an example of one of alternative concepts and implementations. His work titled Observations Relative Chiefly to the Natural History, lume Mineralogical map of the western counties of England was edited by W.G. Maton in a non-standard way. He used single or cross hatchings, creating the effect of different degrees of valour to identify the surface of a given rock strata (fig. 2). In the provided explanations, he identified ten rocks and minerals, among them: 

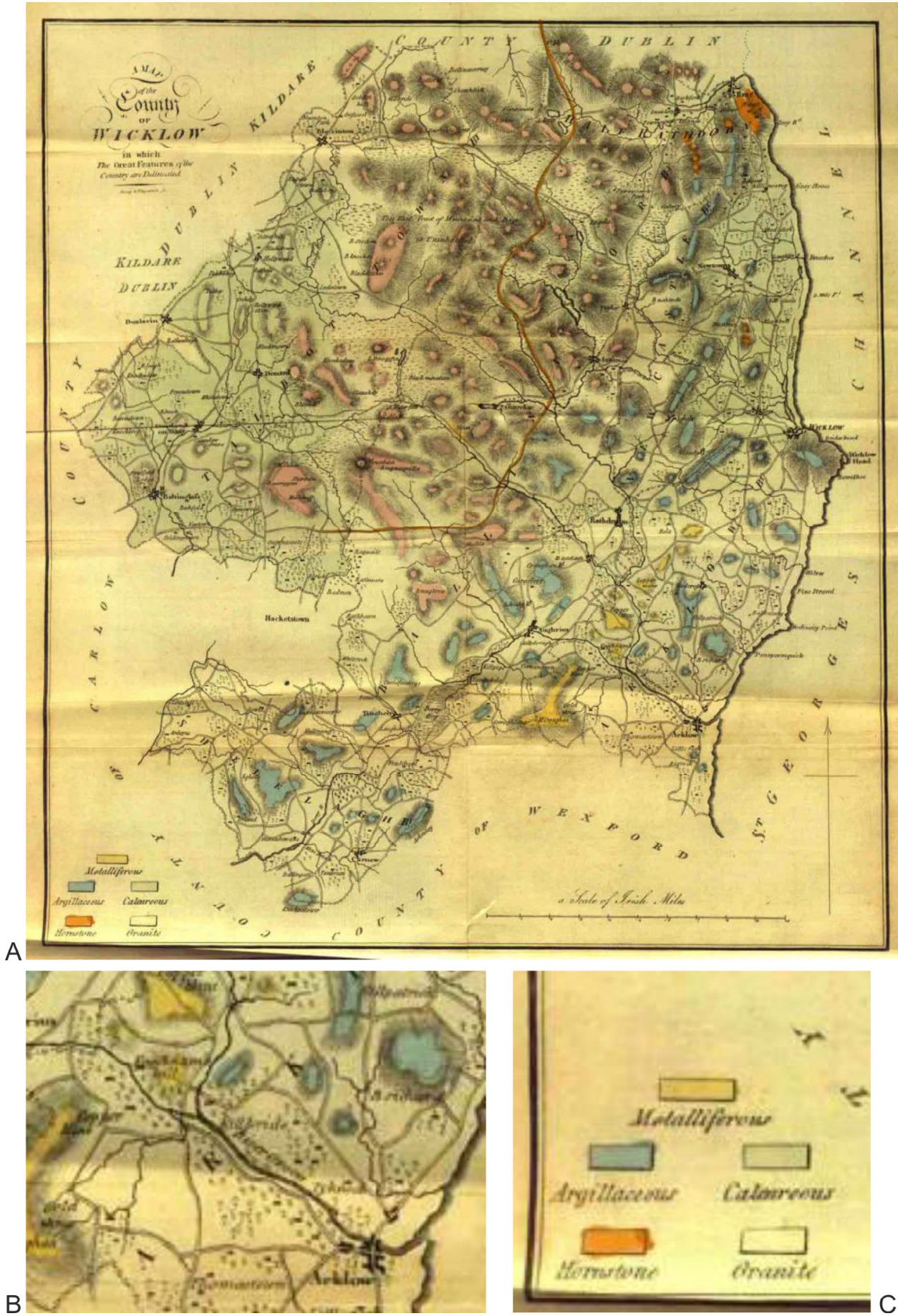

Fig. 3. The map of Wicklow County created by Robert Fraser in 1801 - A, its selected section - B, and the explanation with five categories of rock strata - C (from the collection of the Wicklow County Library) 
chalk, sandstone, clay, killas ${ }^{3}$, serpentinite, quartz, granite and sand.

In the short chapter titled "Observations Explanatory of the Map", which preceded the map included in the book, W.G. Maton defined how he illustrated the studied areas. Explaining why he did not use the colour scale on his map, he wrote that "The method usually adopted for these purposes has been to stain the spaces supposed to be occupied by the several substances with different colours, but these have always appeared to me to be attended with many inconveniencies and imperfections." (W.G. Maton 1797, p. 202). According to him, the best course of action was to apply the method which had been adopted for the first time over a century earlier by Martin Lister (W.G. Maton 1797, p. 203). Further, he wrote that "It would certainly be improper to recommend them as general mineralogical characters, especially when others of an analogous nature may be varied to infinity, - a convenience that cannot be obtained by colours." (W.G. Maton 1797, p. 206).

Despite the assurances of W.G. Maton, the single hatching method was not widely accepted and the vast majority of later creators of geological maps did not use this method. This is true for example for A map of the County of Wicklow in which the Great Features of the County are delineated, a map of Wicklow County located on the east coast of Ireland, published four years later, in 1801, in the book titled General view of the agriculture and mineralogy, present state and circumstances of the County Wicklow by Robert Fraser. In the description of the county, in the section on mineral resources, the author discussed rock strata of the area, systematizing them in the fourth subsection titled "Mountains and General Strata": Granite strata, Hornstone strata, Calcareous strata, Argillaceous strata, Metalliferous strata or Gold Mine (R. Fraser 1801, pp. 13-29). In the explanations provided with the map, he also distinguished the above-mentioned five categories of rock strata, but their area does not cover the entire surface of the map (fig. 3).

At the beginning of the 19th century, the creators of geological maps needed a com-

\footnotetext{
${ }^{3}$ Killas is a mining term used in Cornwall. Rock strata of sedimentary origin are metamorphosed by overlapping granites. In: https://en.wikipedia.org/wiki/Killas (access 06.04.2018).
}

prehensive approach to the development of graphic presentation methods, i.e. the rules of using symbols and colours on maps. Such a set of rules was provided by Robert Jameson, a Scottish geologist and professor of natural history at the University of Edinburgh, who, in the article On colouring geognostical maps published in "Memoirs of the Wernerian Natural History Society" for 1808-1810 in Edinburgh in 1811, described the basic assumptions of drawing and colouring of rock and mineral symbols (D. Oldroyd 2013, p. 79). R. Jameson mentioned five basic principles of using colours which all cartographers should comply with. The first principle he mentioned was: "In every case we must use such colours as will allow the ground-work of the map or delineations of the mountains, to appear through them distinctly". As he mentioned: "The following colours have been recommended by Werner, and I have prefixed to each rock the particular symbol employed by him to distinguish them" (R. Jameson 1811, pp. 150-151 and 155). The writing ends with a model geological map, the explanation of which has been constructed on the basis of twelve colours to distinguish various types of rocks, e.g. gypsum, granite, serpentinite, basalt, porphyry and sandstone. The model river network and relief were drawn as the basic elements, but geographical names were not used (R. Jameson 1811, post p. 160).

\section{French maps as exemplified by the works of Georges Cuvier and Alexandre Brongniart}

In the first years of the 19th century, colours began to be used as a standard to depict the areas of occurrence of specific rock strata. The earlier, simpler maps had fewer categories in legends, and still did not cover the entire depicted area with geological content, just as the above-described map of Robert Fraser from 1801. Another example illustrating this way of presentation was a map of the Paris Basin created by Georges Cuvier and Alexandre Brongniart (1811).

Before developing the geological map of the Paris Basin, A. Brongniart created a reptilian classification system, created the first order of the geologic formations of the Tertiary Period, and also participated in the first extensive study of trilobites. The results of these works became 
useful in determining the age of rocks formed in the Palaeozoic Era. In 1804, in cooperation with a professor of Collège de France, Georges Cuvier, he began studying the locations of fossils occurring in the vicinity of Paris. Carte géognostique des environs de Paris par MM. Cuvier et Brongniart 1810 (A.H. Robinson 1982, pp. 58-59; P. Savaton 1998, pp. 16-19) was an illustration included in the book titled Essai sur la géographie minéralogique des environs de Paris, avec une carte géognostique, et des coupes de terrain published in Paris in 1811. This was the map on which both authors presented the findings of their studies. The 1:200,000 map (with a linear scale in kilometres) was drawn by Bouvelot Junior ${ }^{4}$ on the basis of the Cassini topographic map ${ }^{5}$ (G. Cuvier, A. Brongniart 1811, p. 278), engraved in copper by J.B.A. Cloquet ${ }^{6}$, printed on twelve sheets and hand-coloured (fig. 4A).

The content of the book, and the geological map it contained, popularised the theory of biostratigraphy (paleontological stratigraphy), according to which characteristic fossils found in various sedimentary rock strata can be used for dating individual rock strata. Their publication preceded the achievements of William Smith, a famous British geologist and author of a biostratigraphic map (D. Oldroyd 2013, pp. 41 and 82). After several further years of geological research, G. Cuvier and A. Brongniart developed a different version of the Paris Basin monograph - Description géologique des environs de Paris. Nouvelle editions ..., published in Paris in 1822, with the new version of the Carte géognostique des environs de Paris par MM. Cuvier et Brongniart 1810 et 1822 added (fig. 4C).

The versions of the map differ significantly from one another, but since they were printed using the same copperplate as a basis, many geographic and geological data were left unchanged. For example, some categories indicated in their explanations are identical: the rock strata marked on the maps in pink indicate chalk (craie), while blue points to gypsum (gypse).

\footnotetext{
${ }^{4}$ The map contains the following inscription: Bouvelot fils Del $^{\text {t. }}$ [delineavit].

5 The map contains the following inscription: Nostre carte a été dressee pour la géographique, sur celles de Cassini ....

${ }^{6}$ The map contains the following inscription: Cloquet Sculp.[sculpsit].
}

However, the areas painted with green are classified differently on both maps. On the map from 1811, they are described as the areas containing freshwater (terrein d'eau douce) and marked as areas north-east of Paris, while on the map from 1822, the green marks the upper lacustrine stratum and sandstone (Terrain lacustre supèr. ${ }^{r}$ et meulière), locating them in the areas southwest of Versailles (fig. 4C). On the other hand, the areas located northeast of Paris were marked with greyish blue as middle lacustrine strata and siliceous limestones (Terrain lacustre moyen et Calcaire siliceux). Orange had been previously used to indicate marine marls with gypsum (marnes marines de gypse) and later thick marine limestones (Calcaire grossier marin). Some subcategories were omitted, e.g. soft clays (Argile plastique), siliceous limestone (Calcaire siliceux), commercially-exploited sandstone (Meulières exploitèes) and others. A different selection of explanations reflects well the visible differences in the content of both maps (fig. 4). The writings accompanying the maps provide some additional data, informing the readers that the areas left uncoloured indicate lack of reliable data, and that the dotted lines mark the travel routes of researchers (G. Cuvier, A. Brongniart 1811, p. 278).

The results of research conducted by A. Brongniart on the international geological arena were recognised as great achievements. His theoretical deductions, as well as the progress of the research, reflected in subsequent modifications of his theory, were generally praised, but also sometimes criticised. For example, in 1832 "The Edinburgh New Philosophical Journal", a quarterly scientific journal, published a critical article titled Critical Observations on the Ideas written by a geologist Ami Boué, concerning the classification of A. Brongniart presented in his 1829 work Tableau des Terrains ... The author compares the clay strata in the area around Cologne and in Hesse to the clays classified by A. Brongniart as a argilloarenacious group. Disputing A. Brongniart's claims, A. Boué wrote, among other things, that "On the other hand, if he [Brongniart] separates the plastic clay from the deposits of tertiary clay with lignite, we may ask him the proofs of the lignite clay of Cologne, and the plastic clay of Gross Almerode, in Hessia, being still parts of his argillo-arenacious group. Indeed both localities present characters in opposition 
to those assigned to that group; for at Cologne there are fossil-shells, the fishes of the Dusodile are well known there, and even teeth of the mastodon have been described by Noggerath ${ }^{7}$ as imbedded in that clay. We have then, on the

\footnotetext{
7 Johann Jacob Nöggerath, professor of mineralogy at the University of Bonn.
}

contrary, the zoological characters of his proteique group, or the upper tertiary soil, as given by M. Brongniart himself. In regard to the situation of the Gross Almeroda deposit, the classification rests on purely mineralogical resemblance, which may deceive M. Brongniart in this case, as it has done in that of the plastic clay in the greensand. No certain indication proves the
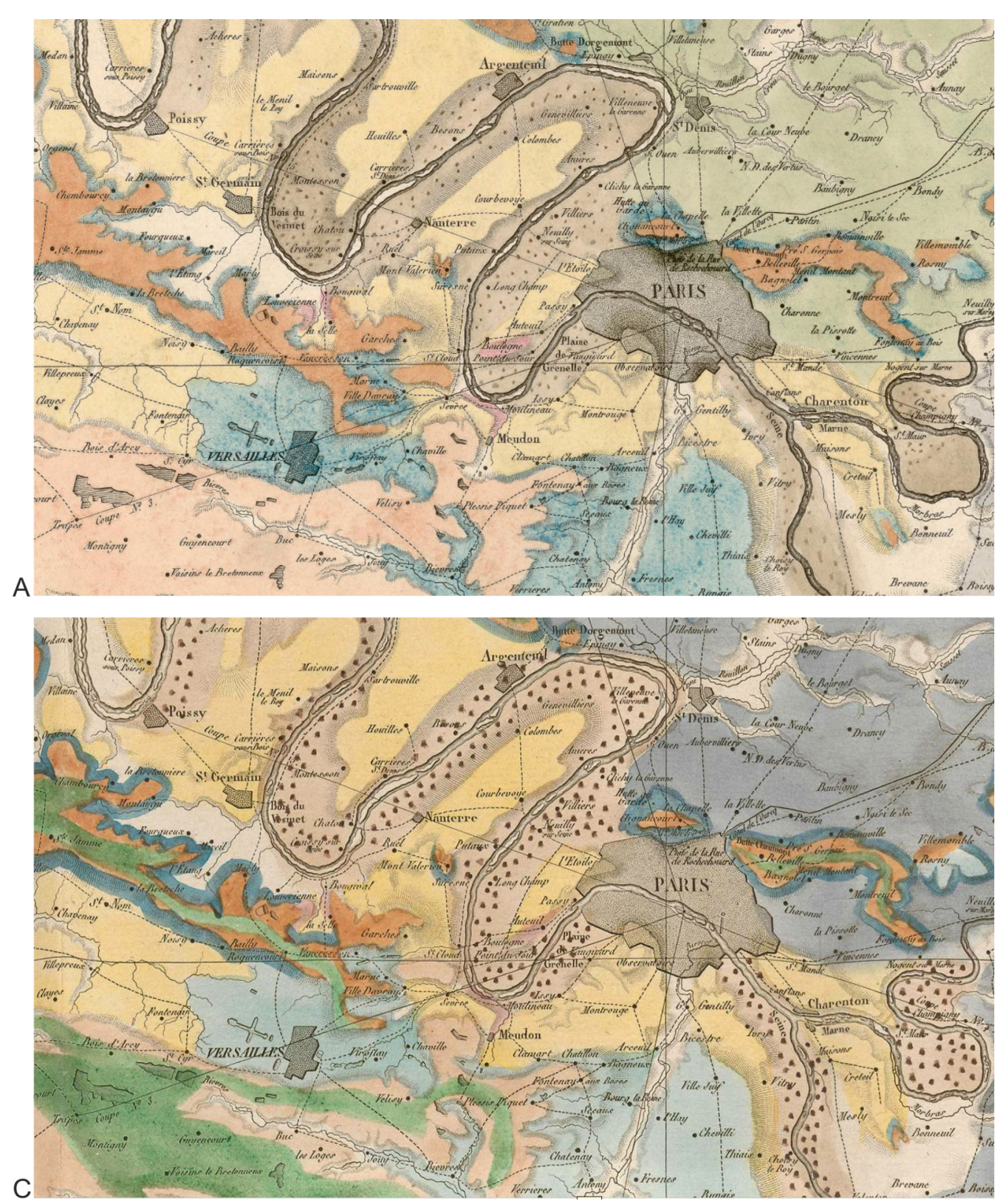


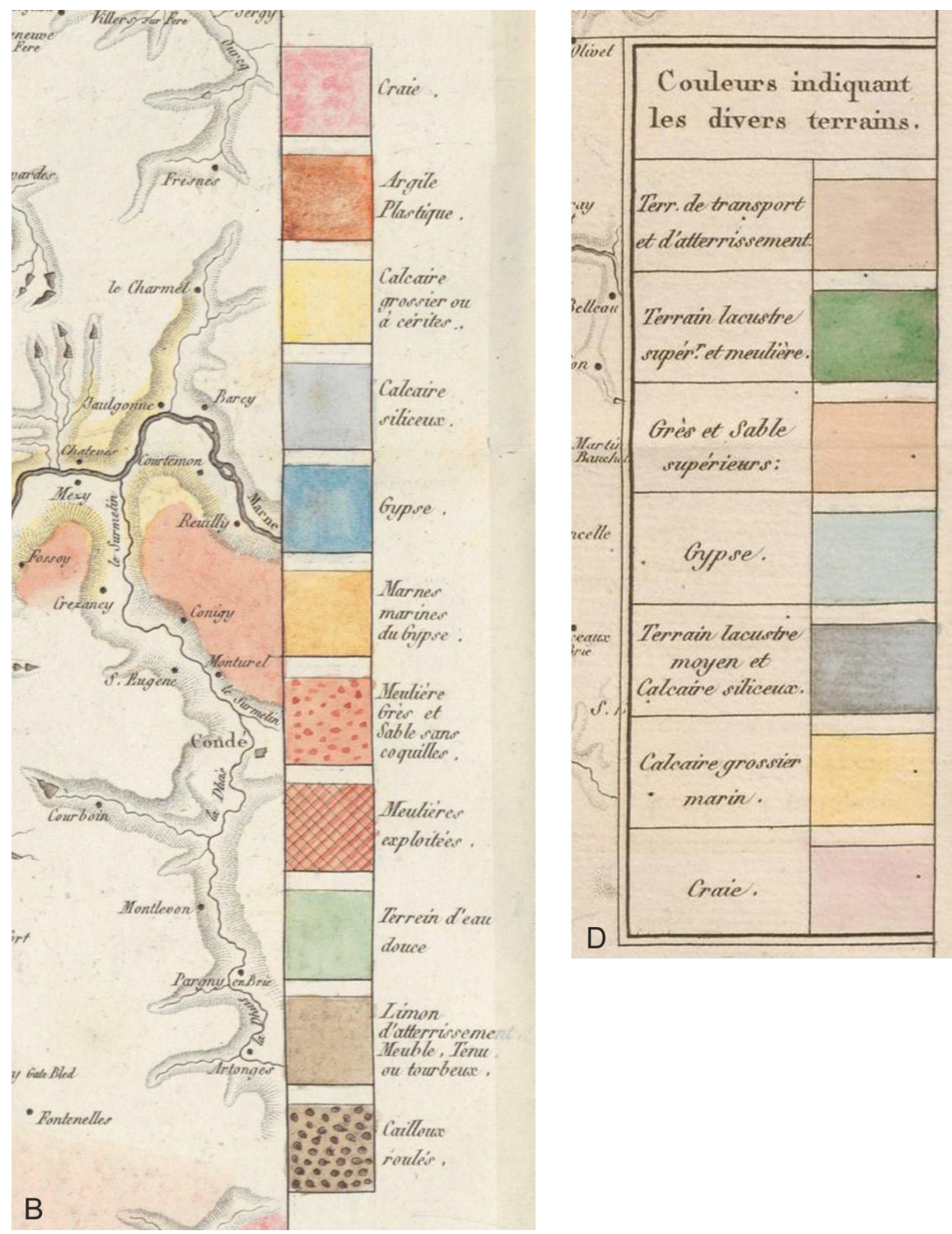

Fig. 4. Comparison of two maps: Carte géognostique des environs de Paris (G. Cuvier and A. Brongniart) published in 1811: a part - $\mathrm{A}$ and the explanation including 11 categories - $\mathrm{B}$ and Carte géognostique des environs de Paris (G. Cuvier and A. Brongniart) published in 1822: a part - $C$ and the legend including 7 categories - D (from the collection of ETH Bibliothek)

justness of this parallelism; in the mean time, the association of this clay with lignite, as well as in the Meissner, is contrary to the characters assigned to plastic clay by M. Brongniart. Further, as he admits in his plastic clay only an extremely fine mechanical deposit, upon which chemical 
action has had some influence ([Brongniart 1829], p. 181); it results, from our limited observations, that plastic clay, or potter's clay, differing but little from the first, occurs in other formations besides those in which M. Brongniart is now willing to admit its presence".

The polemics between the researchers, similar to those quoted above, were a regular occurrence. They facilitated faster development of science and allowed to standardise, or not, the descriptions of rock formations in remote regions of Europe by comparing them with one another, which will be documented below when discussing the Geological Map of Europe ... by Roderick I. Murchison and James Nicol and published in 1849.

\section{British maps exemplified by the works of William Smith}

At the beginning of the 19th century, lithological maps became fully filled with geological content due to many documented geological field studies. William Smith was the first author of such a lithological map which covered the surface of an entire country. Before he developed the map of Britain, he conducted, starting in 1791, extensive field studies of various rock formations during various irrigation works and construction of canals. He noted down his reasoning, writing as follows: "My original method of tracing the Strata by the organized Fossils imbedded therein, is thus reduced to a science not difficult to learn. Ever since the first written account of this discovery was circulated in 1799 it has been closely investigated by my scientific acquaintance in the vicinity of Bath; some of whom search the quarries of different Strata in that district with as much certainty of finding the characteristic Fossils of the respective rocks, as if they were on the shelves of their cabinets." (W. Smith 1817, p. V).

When performing field survey near Bath in 1799, W. Smith developed a map and table containing the basic substantive tenants of stratigraphy associated with the palaeontology of the Baths area ${ }^{8}$. It contains a list of twenty-two rock strata, including, from the surface level: 1. Chalk, 2. Sand, 3. Clay, 4. Sand

\footnotetext{
8 The table has been preserved as a manuscript stored in the library of The Geological Society.
}

\& stone, 5. Clay, 6. Forest Marble... - an overburden of the coal deposits (23. Coal). For the two of the above-mentioned strata, he enumerated the fossils they contained - calcareous skeletons of corals, oysters and other animals in the chalk stratum, and shells of bivalves with a limestone binder in the Forest Marble stratum. W. Smith recorded also shells of ammonites and belemnites in the thirteenth stratum which was made of sand (13. Sand) ${ }^{9}$. What is more, the table contained information about the thickness of the strata, their location in relation to the topographic points and various short comments. W. Smith did not provide explanation for the colours and did not draw a cross-section. Three colours were later reconstructed on the map which accompanied the table (A Map of Five Miles round the City of Bath .... $\left.{ }^{10}\right)$ to mark rock strata: oolites from Bath were marked with yellow, while Lias (15. Lias) was marked with blue and Trias with red ${ }^{11}$.

He made his first attempt to represent the rock strata on a general lithological map of Britain (General Map of Strata found in England $\&$ Wales) in 1801. As the map was preserved in a terrible condition, the colours were reconstructed and made more legible in 1987, on the basis of the colours used by W. Smith in 1815. Eight colours were used for rock strata, e.g. green for Chalk, red for Portland Sand, grey for Oxford Clay, and yellow for Oolites ${ }^{12}$.

However, the most valued work of W. Smith was his map of Britain titled $A$ Delineation the Strata of England and Wales with Part of Scotland exhibiting the collieries and mines, the marshes and fen lands originally overflowed by the sea, and the varieties of soil according to the variations in the substrata, illustrated by the most descriptive names, which was publi-

\footnotetext{
9 Data taken from: https://www.geolsoc.org.uk/Library-and-Information-Services/Exhibitions/William-Strata-Smith/ Stratigraphical-theories/Table-of-strata-in-the-vicinity-of-Bath-1799 (access 06.04.2018).

10 Further data from the map: "on a scale of one inch and a half to a mile, from an Actual Survey, including all the new roads, with Alterations and Improvements to the present time...".

${ }^{11}$ Data taken from: https://www.flickr.com/photos/geologicalsocietylibrary/15796985838/

12 Data taken from: https://www.geolsoc.org.uk/Library-and-Information-Services/Exhibitions/William-Strata-Smith/ The-Map/General-Map-of-Strata-found-in-England-and-Wales-1801 (access 06.04.2018).
} 

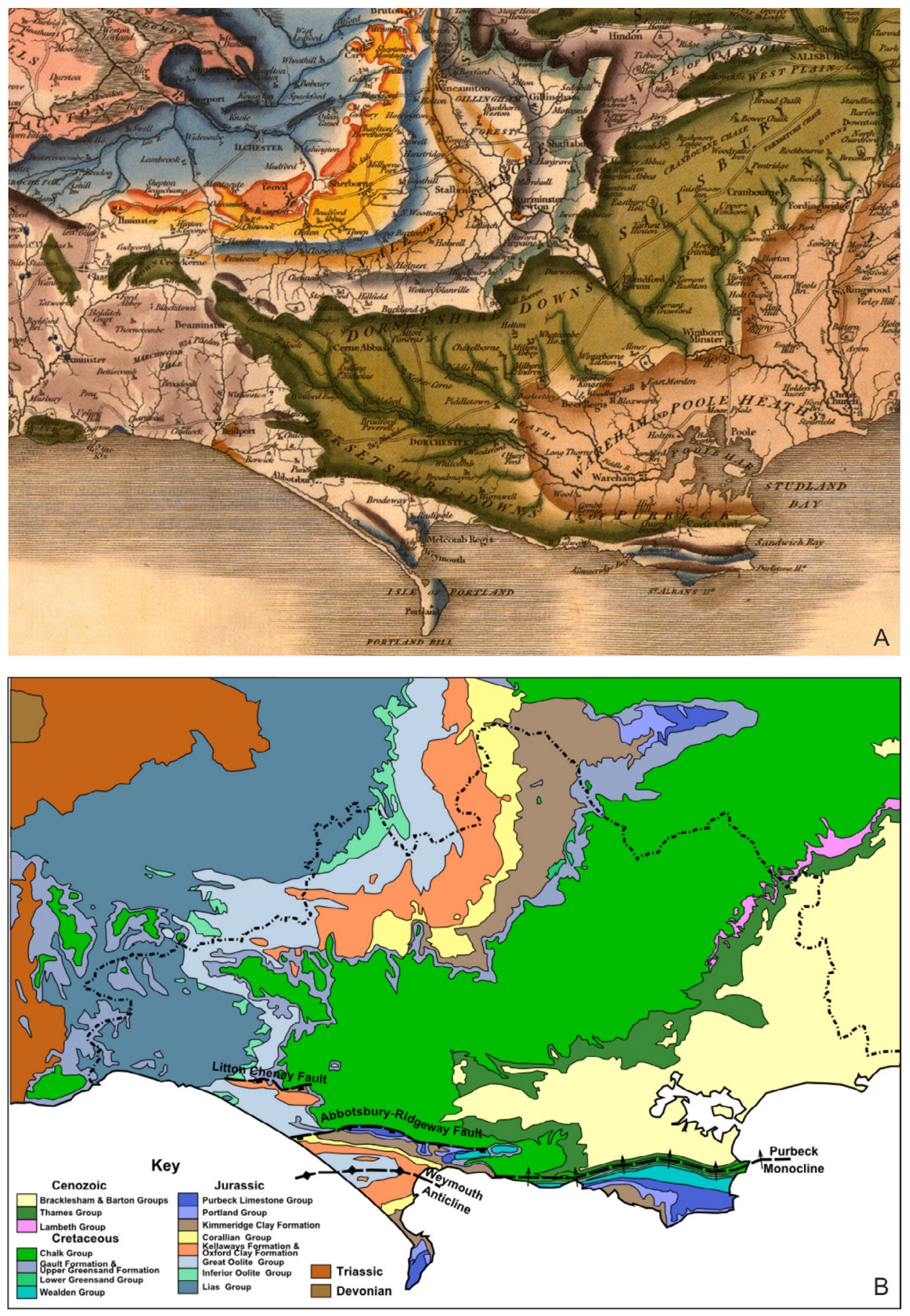

Fig. 5. Presentation of the geology of Dorset County on the part of: A - the W. Smith's map of 1815 (from the collection of the Princeton University Library) and B - the M. Norton's map Dorset Geology created on 22 July 2012, https://en.wikipedia.org/wiki/Dorset (access 19.06.2018) 
shed using a scale of approximately 1:316,800, had the total dimensions of $2.4 \times 1.8 \mathrm{~m}$, included topographic content (without relief) developed by the cartographer and publisher John Cary, and was printed from copperplate on fifteen sheets, with hand-coloured geological content made by craftsmen under the direction of the author in 1815 (A.H. Robinson 1982, p. 60). The section of the map depicting Dorset County was selected for this article for the purpose of discussing its geological content ${ }^{13}$.

Dorset County, located in the south-west of England, is characterised by high variability of landscape types, caused, as shown on W. Smith's map, by the complex nature of rock formations of the area, which is demonstrated in figures $5 \mathrm{~A}$ and $5 \mathrm{~B}$ depicting parts of both maps - W. Smith's map from 1815 and Mike Norton's map from $2012^{14}$. More than a half of the county's area is made of chalk sands, clays or sands and gravels (fig. 5A). In the central part of the county, the rocks form a varied landscape with wide valleys made of chalk land Rocks and Purbeck stone, marked in blue, as well as Kimmeridge Clay and Brickearth, marked on W. Smith's map with brown and on Mike Norton's map with yellow, Oxford Clays, marked with grey, a group of oolite rocks (Great Oolyte Rock), marked on W. Smith's map with yellow and on M. Norton's map with grey, as well as lias, which is marked with greyish blue on both maps (W. Smith 1815, pp. 18-19). An analogous presentation of rock strata is shown by M. Norton's map (fig. 5B), and the explanations show that these formations were formed in various periods, from the Devonian to the Caenozoic Era, and that most of the rocks were created in the Jurassic and Cretaceous Eras.

Without going into the details of the map, it is clear that Dorset County was already well-analysed in terms of its rock types in the first twenty years of the 19th century, as demonstrated by a comparison of lithological maps, separated from each other by nearly two hundred years of successively more and more advanced measurements and field studies.

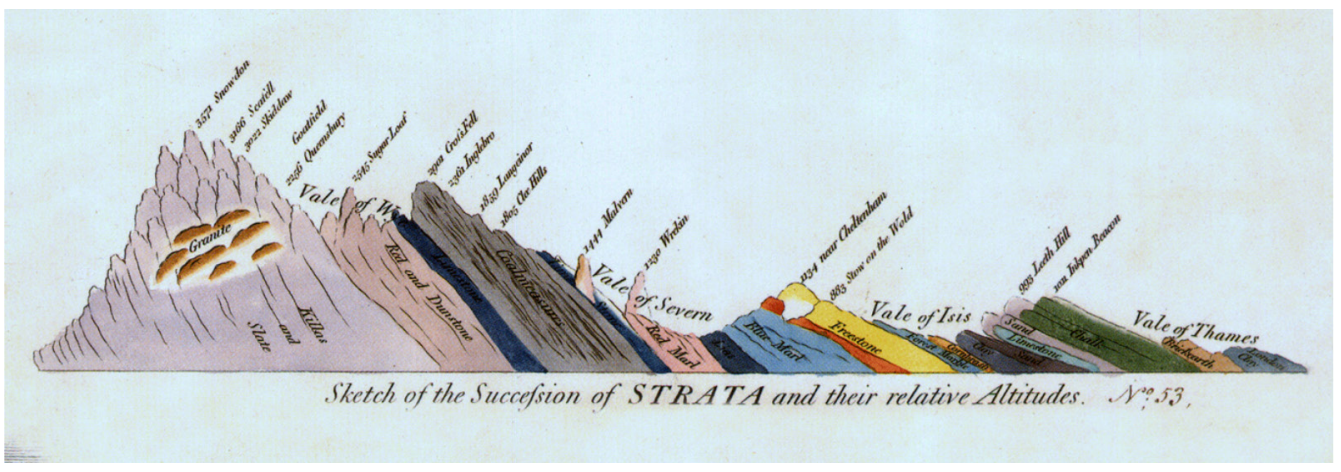

Fig. 6. A geological section of rock strata on the map A Delineation of the Strata of England and Wales with Part of Scotland ... by W. Smith, 1815 (from the collection of The Geological Society of London)

rocks (marked in green), with steep limestone ridges and low-lying valleys made of clays. On the other hand, the southern part of the county, adjacent to the English Channel coast, and the northern part of the county, are made of Port-

\footnotetext{
13 The rock strata of the county were also illustrated above in figure 2, when discussing the W.G. Maton's Mineralogical map of the western counties of England published in 1797.

${ }^{14} \mathrm{~A}$ part of a modern geological map presented on-line.
}

W. Smith's map is supplemented by a geological cross-section depicted on the right. It presents individual rock strata of particular lithological types, sometimes accompanied by the name of the town or other geographical location in which they were described. The cross-section helps to understand not only the image of rocks visible on the surface, but also the spatial arrangement of their deposits (fig. 6). 
The map is accompanied by a brochure $A$ memoire to the map and delineation of the Strata of England and Wales with part of Scotland which was also published in 1815 and explained the presentation method. The author wrote, for example, that "The courses of the strata, or the length and breadth of surface occupied by each as they rise successively from the level of the sea on the eastern to the western side of the island, are represented by colours" and below that "The colours, though brighter than those they represent, are in some degree assimilated to the colour of each stratum, except the chalk, which, being colourless, seemed best represented by green, strong colours being necessary, and no stratum of equal extent requiring that colour" (W. Smith 1815, p. 7).

The reasoning for choosing this method of presenting the geological structure of Britain on the general map was provided by W. Smith not only in the above-mentioned writing, but also on the sheet titled Explanation of colours on the Map of Strata, taken in Succession from East to West, as the Strata occur (fig. 7A). The author was aware of the inconvenience of deciphering various colour categories, which is made clear in his statement that "In some cases, where the strata are much alike, as the oolytes, Nos. 7 and 12, they are represented by light and dark yellow...." (see fig. 7B) and below "The black shades represent the coal measures, or the strata which generally contain coal, more or less valuable, several beds of which are too thin for working. The most productive parts are described by the darker shades, which abound with numerous crosses, the sites of the collieries" (W. Smith 1815, p. 8).

After gaining the research experience and developing A Delineation of the Strata of England and Wales with Part of Scotland, W. Smith could write: "The result of my labours is a settled plan for doing this, and therefore the identification of Strata by the help of organized Fossils, becomes one of the most important modern discoveries in Geology. It enables the Geologist clearly to distinguish one Stratum from another in Britain, and also to trace their connexion with the same Strata on the continent. Thus it is capable of the most extensive or of the most local use. Strata, when identified by organized Fossils, with the localities of each Stratum accurately delineated, will also define on maps of the country the limits of districts in which they are most prevalent." (W. Smith 1817 , pp. VII-VIII).

\section{German maps as exemplified by the works of Leopold von Buch}

The paper has so far presented two maps based on their authors' own field studies: the map of the Paris Basin created by G. Cuvier and A. Brongniart and the map of Britain created by W. Smith. The multi-sheet geological map of Germany Geognostische Karte von Deutschland und den umliegenden Staaten in 42 Blättern nach den vorzüglichsten mitgetheilen Materialien, issued in the form of an atlas, was also based on the research conducted by its author, Leopold von Buch, a member of the Berlin Academy of Sciences. It was published at a scale of about $1: 1,000,000$ on 42 sheets and printed using copperplate matrices in Berlin, at the printing house of Simon Schropp et Comp, in 1826 (S. Wołkowicz 2016, pp. 367-368; A.J. Wójcik 2012, p. 184; A.J. Wójcik 2013, p. 20).

For obvious reasons, just as the above-described maps, the map of L. von Buch was a compilation of earlier maps presenting German regions, such as the maps of Carl von Raumer and August Kaluža (S. Wołkowicz, K. Wołkowicz 2014, p. 629; S. Wołkowicz 2016, pp. 362-367). In addition, L. von Buch used materials collected in Teutschland geognostisch-geologisch dargestellt, a book written by Christian Keferstein, a lawyer and amateur-geologist, which was published in Weimar by Landes-Industrie-Comptoirs, in 1821, and accompanied by a map of the whole country, General Charte von Teutschland auf der vom Hauptmann Weiland gezeichneten Charte Geognostisch begraenzt, which was drawn by K.F. Wieland, a cartographer, and printed at a scale of about $1: 2,300,000$ with a hand-coloured copperplate printing technique (A.J. Wójcik 2013, p. 19).

While the map of $\mathrm{Ch}$. Keferstein had eleven categories of rock formations, such as: granite and gneiss (Granite - Gneuss Formation), schists (Schiefer), red sandstone (Rother Sandstein), alpine limestone (Alpen Kalk), porphyry (Porphir Steinkohlen), colourful sandstone or Buntsandstein (Bunter Sandstein), Muschelkalk (Muschel Kalkstein), Jurassic limestone (Jura Kalkstein), basalt (Basalt) and chalk (Kreide), the map of L. Buch had forty-five categories. 
The entire map sheet was taken up by the explanation of colours (Erklaerung der Farben). Such a large number of categories identified only by means of their colours would be unreadable on the map, so the author numbered the individual categories and distinguished some of them with patterns. Thus, the colourful sandstone (18 Bunter Sandstein) is not only marked as orange, but also with a pattern made of horizontal dashed lines (see fig. 8).

French and/or English terms were added to German names of rock formations, e.g. granite

\section{EXPLANATION.}

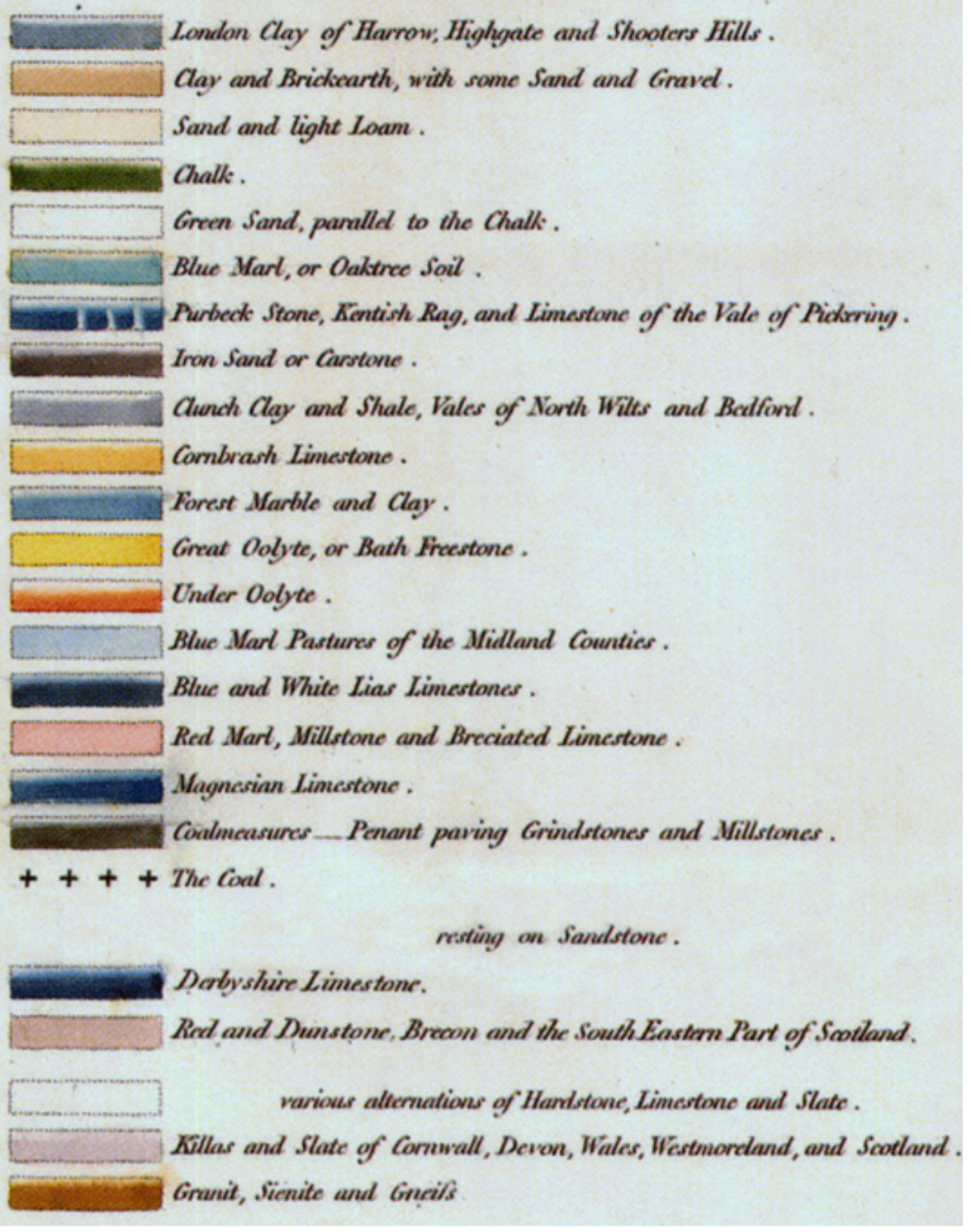




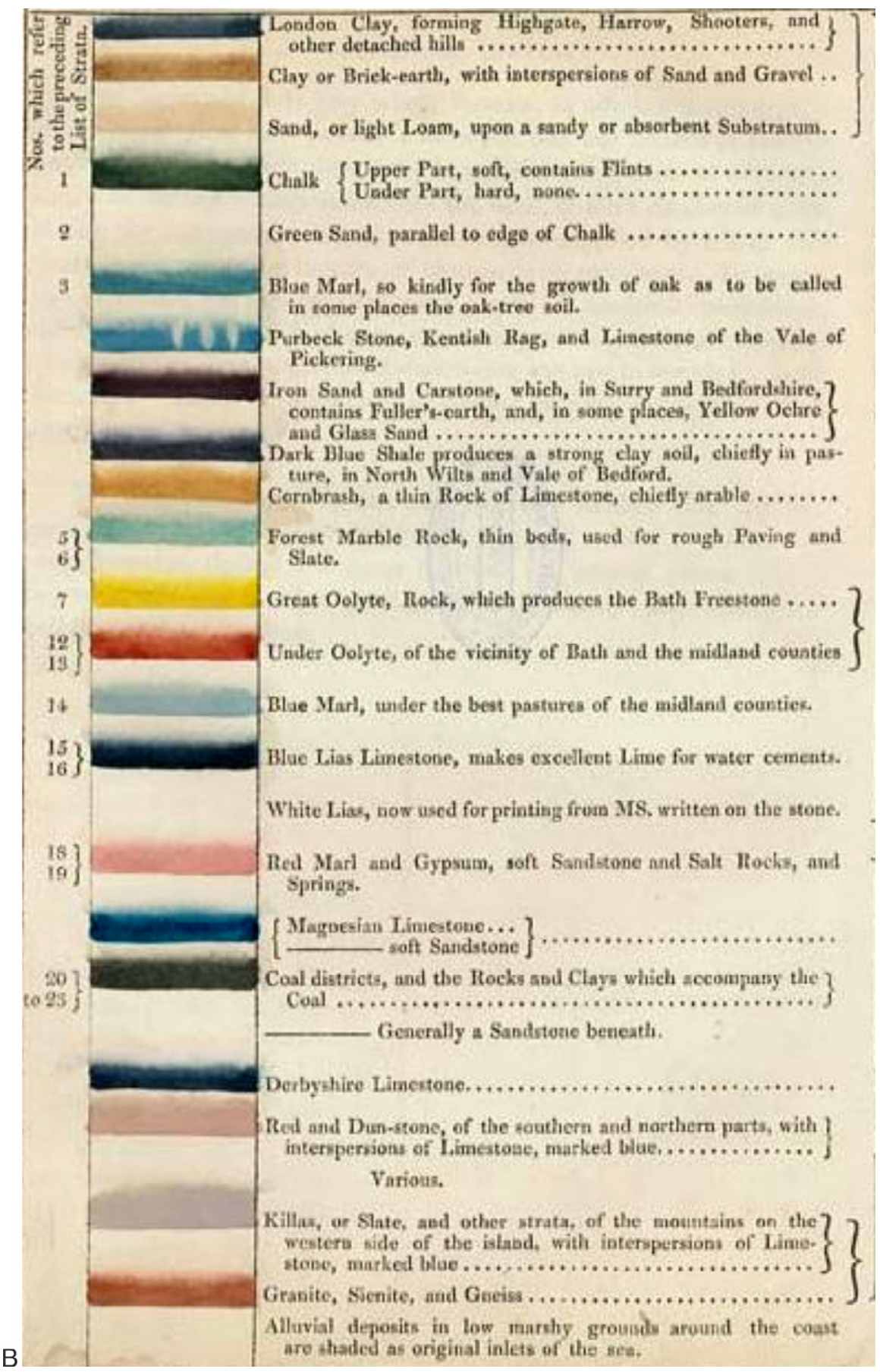

Fig. 7. Comparison of two colour explanations used by W. Smith: A - on A Delineation of the Strata of England... (1815), and B - on the sheet containing his writing titled A memoire to the map... (1815) (from the collection of The Geological Society of London) 

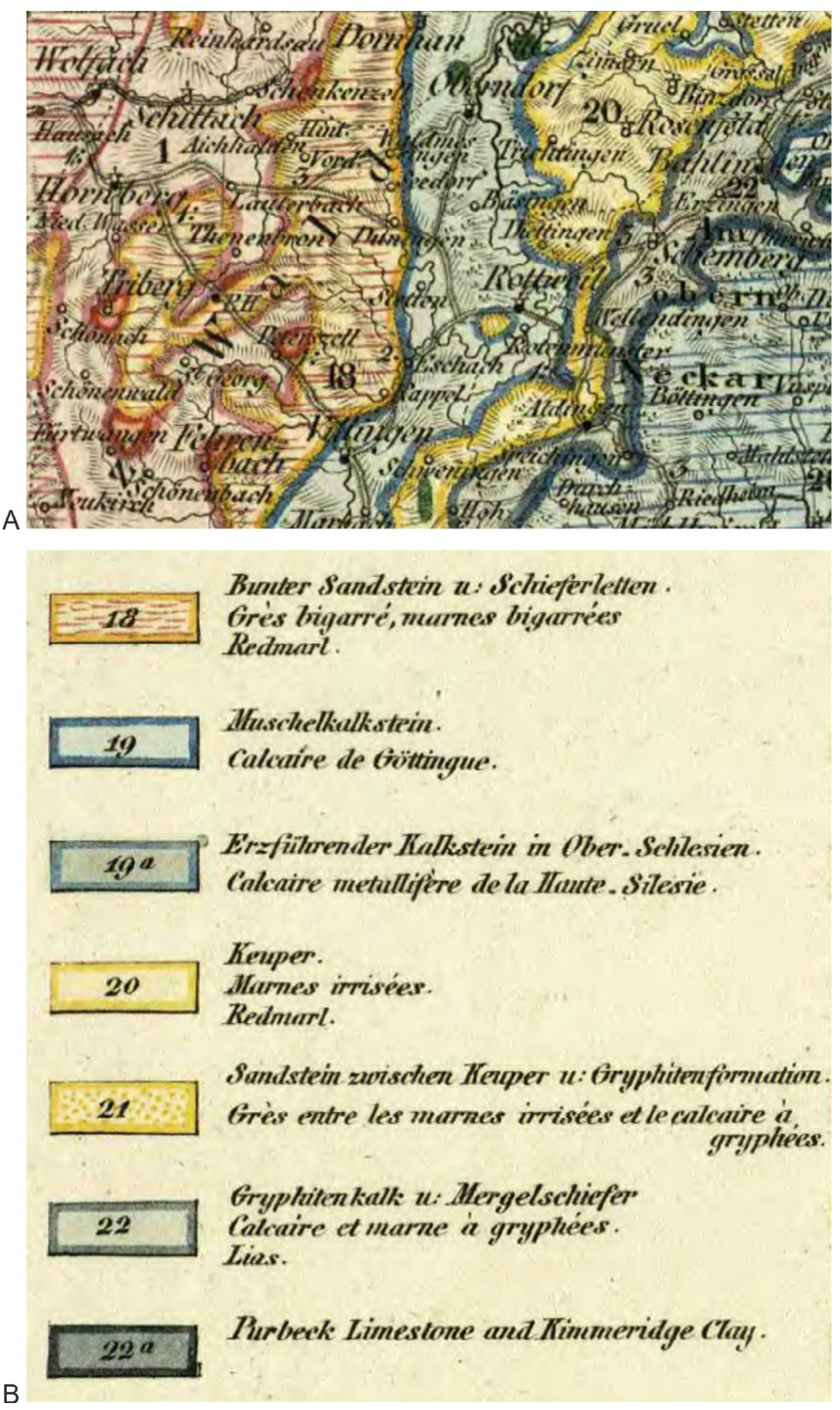

Fig. 8. Part of the sheet München from the map of Leopold von Buch, Geognostische Karte von Deutschland... - A and its explanation - B (from the collection of the Central Library of Geography and Environmental Protection, Polish Academy of Sciences) 
(1 Granit - Weisstein, Granite Eurite), gneiss (2 Gneus, Gneis), Muschelkalk (19 Muschelkalkstein, Calcaire de Göttingue), marl (20 Keuper, Marnes irrisées, Redmarl), Jurassic oolitic limestone (23 Oolithischer Jurakalk, Calcaire oolithique jurassique, Inferior Oolithe and Sandy Beds). Some categories were named only with English terms, for example limestone and clay (22a Purbeck Limestone and Kimmeridge Clay), and chalk (26a Kreide, Craie Blanche, Chalk). This multilingual explanation in the map constitutes evidence of the desire to show the presence of similar formations in different parts of Europe. However, categories in only one language constitute names borrowed from rock formations discovered and described in specific places.

The analysis of deliberately selected three maps: the maps of Paris Basin, Britain and Germany, as well as the written studies of Georges Cuvier, Alexandre Brongniart, William Smith and Leopold von Buch, all of whom had great scientific achievements at the beginning of the nineteenth century - demonstrated the scientists' cooperation in solving the problems of depicting rock strata, which resulted in the systematic development of geological sciences and allowed for creating a compendium of geological knowledge in the form of lithological maps of Europe issued in print in the mid-nineteenth century.

\section{Lithological maps of Europe in the atlases of Heinrich K. Berghaus and Alexander K. Johnston}

The 1830s were the next stage in the development of research and descriptions of rock strata. This period was also the stage of further attempts to systematise geological knowledge concerning formation and construction of rock complexes, mainly on the basis of fossils which continued to be successively discovered and classified by palaeontologists. The list the most innovative of such attempts should begin with the two-volume monograph of Charles Lyell titled Principles of Geology published in 1830-1833, in which the author, in the eighth chapter, provided a description of rock strata, creating a classification and making the description more orderly. As the first one (the earliest), Lyell presented "the period of the deposition of the carboniferous strata, give rise to an extremely hot climate. Origin of the transition and mountain limestones, coal-sandstones, and coal. Change in the physical geography of northern latitudes, between the era of the formation of the carboniferous series and the lias. Character of organic remains, from the lias to the chalk inclusive, State of the surface when these deposits originated. Great accession of land, and elevation of mountain-chains, between the consolidation of the newer secondary and older tertiary rocks. Consequent refrigeration of climate. Abrupt transition from the organic remains of the secondary to those of the tertiary strata - Maestricht beds. Remarks on the theory of the diminution of central heat" (Ch. Lyell 1830, vol. 1, pp. 125, 139-140).

In 1831, in A Geological Manual, Henry De la Beche for the first time used the work of his precursors to present the following classification of rocks found in Europe. First of all, he divided rocks into two classes: Primitive and Secondary (later referred to as Mesozoic). According to $\mathrm{H}$. Beche, A.G. Werner added the third class of transitional rocks (cf. page 88), while G. Cuvier and A. Brongniart added a fourth class called Tertiary because, as $\mathrm{H}$. Beche explained, this stratum was composed almost entirely of chalk, but it was located above the Mesozoic class (Secondary). The author further claimed that such a division had been in use, only with minor changes, until 1833. From another point of view, rocks could still be divided into Stratified (ones which formed strata) and Unstratified (those which did not). The former contained fossiliferous elements and were, according to $\mathrm{H}$. Beche, in their mass composed of accumulated organic remains characteristic for a given formation and, as the author noted, occurring in various rock complexes which were often located far apart from one another. For his own needs, $\mathrm{H}$. Beche created a new classification consisting of 1-8 groups of rocks and presented it in the table $(\mathrm{H}$. Beche 1833, pp. 35-36, 38-39), which was then used in descriptions of rocks in particular regions of Europe and the world.

This paper has described several rock classifications because their versions - more or less similar to the ones quoted - order the categories in the explanations explaining symbols used on the maps published before the midnineteenth century. Before lithological maps of Europe were created in the atlases of Heinrich 

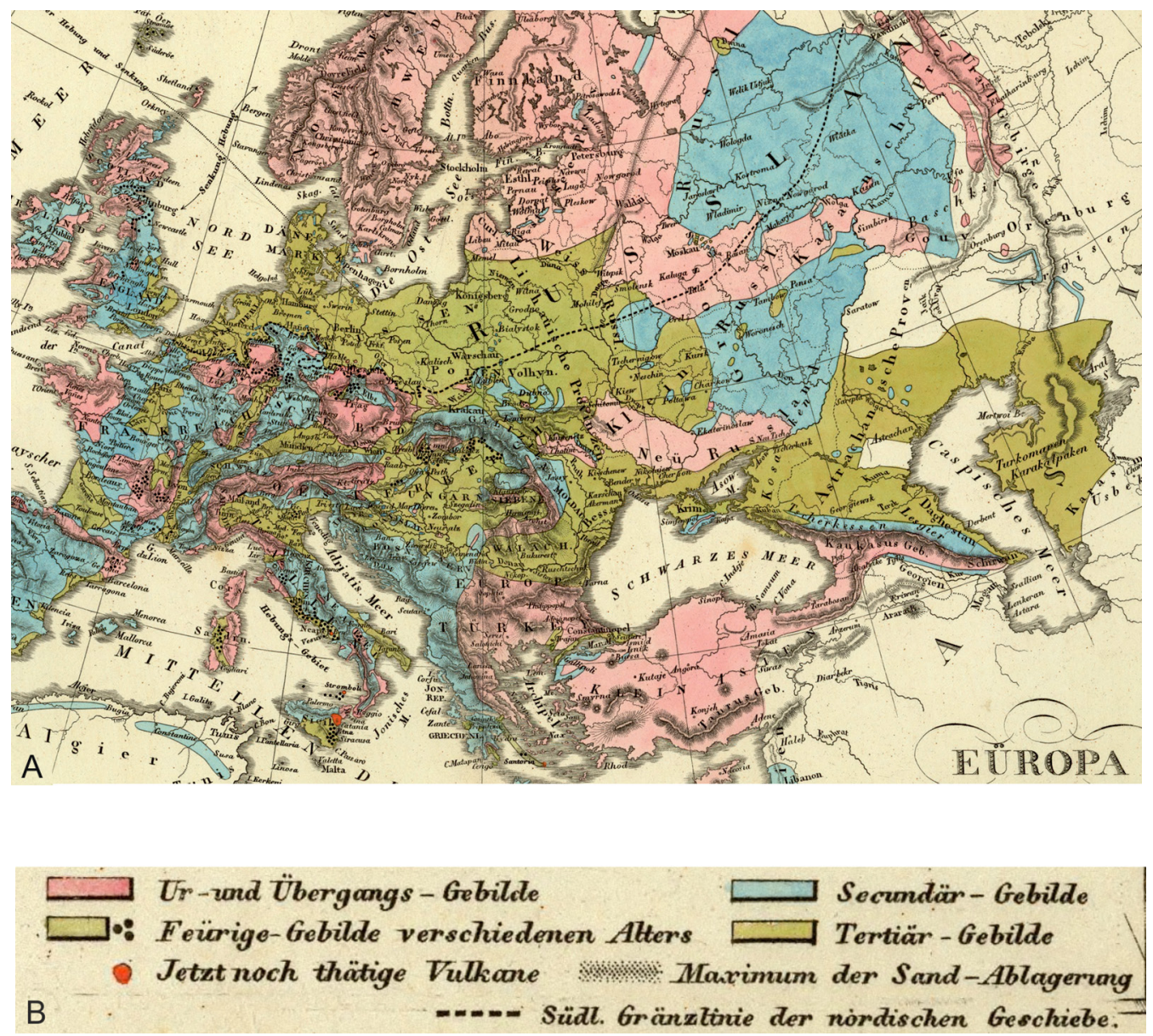

Fig. 9. Part of the map Europa in Geologischer Beziehung by H.K. Berghaus - A and its explanation - B (from the David Rumsey Map Collection)

Karl Wilhelm Berghaus and Alexander Keith Johnston, many geologists involved in the development of maps and explanatory writings prepared their own more or less accurate classifications of rock strata to be able to depict how the strata coexisted and what were their individual ranges. In order to select publications which at that time were considered to be the most important ones, I will use here the selection made by $\mathrm{Ch}$. Keferstein, a lawyer, amateur-geologist, and the author of the abovementioned map of Germany from 1821, in his monograph Geschichte und Litteratur der Geognosie, published in 1840. After discussing the achievements of geologists in Denmark, Norway and Sweden, he briefly commented on the description of Polish territories by Georg Gottlieb Pusch in 1833-1837 titled Geognostische General Karte von den Königreichen Polen und Galizien (Ch. Keferstein 1840, pp. 220-221; A.J. Wójcik 2013, p. 22) and further - the description of the lands of northern Russia created by W. Strangways ${ }^{15}$ in Strata des environs de St. Petersbourg..., published in 1819 (Ch. Kefer-

\footnotetext{
15 The surname "Strangways" can be seen on Carte géologique de la Pologne d'apres Mrs Buch, de Lilienbach, Strangways, Pusch, Eichwald, etc. according to A.J. Wójcik (2013, p. 12).
} 

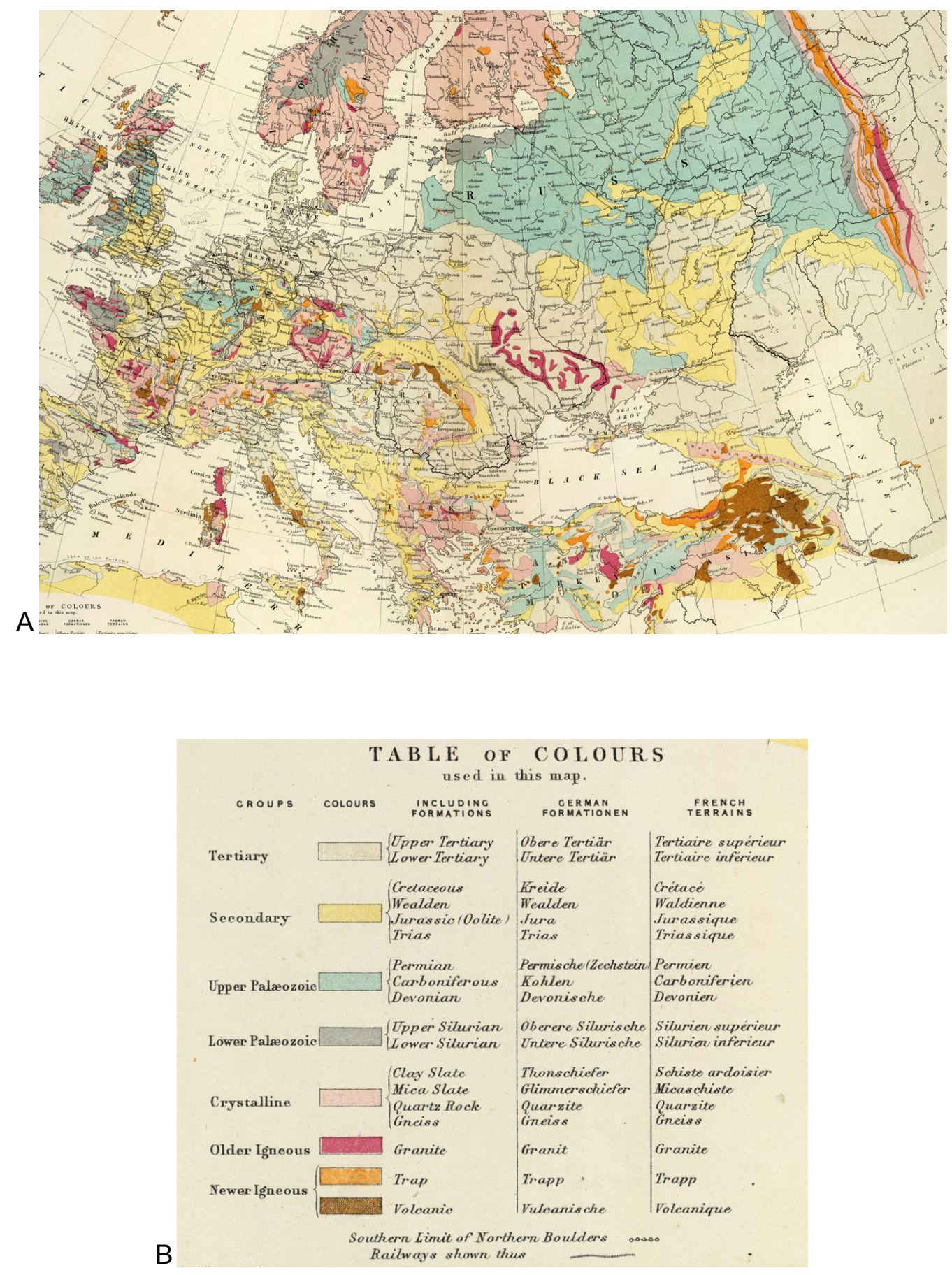

Fig. 10. Part of Geological Map of Europe created by Murchison and Nicol - A and its explanation - B (from the David Rumsey Map Collection) 
stein 1840 , p. 221). A lot of knowledge about the past state of geological studies in European countries can be found in the reports of geological societies, including the British one, which were published in "Proceedings of the Geological Society of London", for example for 1838-1842. Their publication immediately preceded the development and publication of the map created by $\mathrm{H}$. Berghaus, and the map was probably based partially on the data it contained.

I want to present the map of Heinrich K.W. Berghaus Europa in Geologischer Beziehung (1843) by comparing it with Geological Map of Europe published about 10 years later in the atlas created by Alexander K. Johnston in 1856. The juxtaposition of these maps, and in particular their explanations, shows how quickly changes in the classification and naming of rock strata occurred at the end of the first half of the 19th century.

Both maps were published in thematic atlases. The older of the two, Physikalischer Atlas oder Sammlung von Karten, auf denen die hauptsachlichsten Erscheinungen der anorganischen und organischen Natur nach ihrer geographischen Verbreitung und Vertheilung bildlich dargestellt sind developed by H.K.W. Berghaus, was published in two volumes by Justus Perthes in Gotha in 1845-1858 and contained seventy-five maps on ninety sheets (J. Espenhorst 2003, pp. 375-377; A.H. Robinson 1982, pp. 65-66, 91). Europa in Geologischer Beziehung nach den Hauptmassen der GebirgsFormationen, Gotha, bei J. Perthes 1843, was printed among those 75 maps, in the first volume, in the third chapter ("Geologie"), as the map "No. 4". It was a hand-coloured 1:17,000,000 map, printed using lithography (A.J. Wójcik 2013, p. 24). As its full title suggests, it depicted active volcanoes and both the oldest and new mountain ranges on the whole continent. The explanation of this map contains only seven categories, and their order seems to be accidental (fig. 9).

Formations of rock strata are explained in part on the basis of the division proposed by A.G. Werner in 1774 (see above, chapter 3) - the primordial and transitional formations (Ur[anfängliche] - und Übergangs - Gebilde) are marked using red colour. Former eruptive deposits and active volcanoes were marked as separate groups, blue indicated Mesozoic formations (Secundär - Gebilde), and green-yellow indicated Tertiary formations (Tertiär Gebilde). The dashed line marked the southern boundary of erratic rocks which had been moved there from the north, and a streak made out of dots - the maximum range of sandy alluvial deposits (Sand - Ablagerung) drawn in the northern part of European Russia. In addition, a dotted line linking Iceland and a part of the North Sea to Scandinavia has been drawn on the map, without any explanation in the legend, and called the limit of heights and lows (Gränze der Hebung und Senkung).

Artur H. Robinson wrote about The physical Atlas of Natural Phenomena, created by A.K. Johnston and published for the first time in 1848, that it was an English-language copy of the atlas of H.K. Berghaus (A.H. Robinson 1982, pp. 66-67). The second Edinburgh edition of 1856 (William Blackwood \& Sons) also consisted mostly of maps copied from the German edition. However, the map of Europe, Geological map of Europe, exhibiting the different systems of rocks according to the most recent researches and unedited materials, for Keith Johnston's Physical atlas..., was an original map developed especially for this edition of the atlas. Its authors were Scottish geologists: one of the founders of the Royal Geographical Society, Roderick Impey Murchison, and a professor at the University of Aberdeen and a member of the Geological Society in London, James Nicol. Their 1:9,500,000 map was published in the fourth section of the atlas, "Geology no. 4", as a coloured lithography.

As shown in figure $10 \mathrm{~B}$, the ranges of rock formations depicted on the map created by R.I. Murchison and J. Nicol are not very similar to those which can be seen on the map of H.K. Berghaus. On the German map, the areas of northern Europe - Scotland, Scandinavia, Finland, northern European Russia and central Ural - are depicted as consisting of primeval rocks and correspond to the formations of crystalline and eruptive rocks on the map of Murchison and Nicol. The formations on the land of the Czechia, Brittany and the Central Massif are depicted as areas composed of the same rocks. The only difference is the fact that the Murchison and Nicol's map shows in this areas additional formations classified as rocks from the Lower Paleozoic, which are marked with grey, and crystalline rocks marked with 
light pink. The existence of the formation from the Mesozoic Era (Secondary or Secundär, in German) in the vast areas of the European part of Russia overlap only to a small degree. R.I. Wolffison and J. Nicol classified the rocks located in those areas as originating from the Upper Palaeozoic - from the Permian, Carboniferous and Devonian periods - and marked them with blue, while H.K. Berghaus also marked these areas mainly with blue, but described them as the Mesozoic Era formations (Secundär).

The comparisons of the two maps, as well as any further comparisons with other maps developed in the mid-nineteenth century, were made undoubtedly easier by the trilingual explanations provided in the "Table of colours used in this map" on the British map (fig. 10B). It shows also that European geologists must have had already reached at that point a broad agreement on the chronological classification of rock formations.

\section{Literature}

Beche H. De la, 1833, A Geological Manual. Third edition considerably enlarged. London: Charles Knight.

Boué A., 1832, Critical Observations on the Ideas of $M$. Alexander Brongniart, relating to the Classification and probable Origin of Tertiary Deposits. "The Edinburgh new philosophical journal, exhibiting a view of the progressive discoveries and improvements in the sciences and the arts" Vol. 5, pp. 159-172.

Brongniart A., 1829, Tableau des Terrains qui composent l'ecorce du Globe ou Essai sur la structure de la partie connue de la Terre. Paris: Leveault F.G.

Cuvier G., Brongniart A., 1811, Essai sur la géographie minéralogique des environs de Paris, avec une carte géognostique, et des coupes de terrain ... Paris: Baudouin, Imprimeur de I'Institut Impérial de France.

Cuvier G., Brongniart A., 1822, Description géologique des environs de Paris. Nouvelle éditions, dans laquelle on a inséré la description d'un grand nombre de lieux de l'Allemagne, de la Suisse, de l'Italie, etc., qui présentent des terrains analogues à ceux du bassin de Paris... Avec 2 cartes et 16 planches... Paris: Chez G. Dufour et E. d'Ocagne, libraires.

Desmarest N., 1771, Memoire sur l'origine \& la nature du Basalte à grandes colonnes polygones, déterminées par l'Histoire Naturelle de cette pierre, observée an Auvergne. "Histoire de l'academie

\section{Summary}

The characteristic feature of lithological maps, whose development began at the turn of the 18th and 19th centuries and continued until the mid-nineteenth century, was the fact that they combined rock strata into formations based on the similarities of features of the rocks they included, established the chronological order inside rock formations and strata on the basis of fossils and reconstructed geological history of individual regions, as well as tried to combine the acquired knowledge and use it to describe larger areas - continents. The ending of the discussion of the lasting achievements of geological sciences of that period is perfectly summarised and illustrated by Geological Map of Europe published by A.K. Johnston in 1856, whose authors, in both explanatory and geological content of the map, linked their observations and research conducted in individual countries into one coherent visualization.

royale des sciences", pp. 705-775, a map (from the collection of the Linda Hall Library).

Espenhorst J., 2003, Petermann's Planet. A Guide to German Handatlases and their siblings throughout the World 1800-1950. Vol. I: The Great Handatlases. Schwerte: Pangaea Verlag.

Feller F.-X. de, 1848, Nicolas Desmarest. In: Biographie universelle. Paris: J. Leroux, Jouby et Chalandre, Vol. 3, p. 217.

Fraser R., 1801, General view of the agriculture and mineralogy, present state and circumstances of the County Wicklow, with observations [...] drawn up for the consideration of the Dublin Society... Dublin: Printed by Graisberry \& Campbell.

Füchsel G.C., 1761, Historia Terrae et Maris ex Historia Thuringiae, per montium descriptionem eruta a... "Acta Academiae Electoralis Moguntinae scientiarum utilium quae Erfordiae Est" Vol. 2, pp. 44-208 and Eiusdem usus Historiae suae Terrae et Maris, pp. 209-254, Erfordiae: apud Johannem Fridericum Weberum.

Gohau G., 1990, A history of geology. New Brunswick, London: Rutgers University Press.

Gümbel C.W., von, 1878, Georg Christian Füchsel. In: Allgemeine Deutsche Biographie. Leipzig: Dunkker \& Humblot, Vol. 8, p. 175.

Gümbel C.W., von, 1883, Johann Gottlob Lehmann, in: Allgemeine Deutsche Biographie. Leipzig: Dunkker \& Humblot, Vol. 18, pp. 140-141. 
Hacker W., 2009, Geowissenschaften und Bergbaugeschichte in der Dreiländer-Region Hessen, Thüringen, Niedersachsen. Ergänzte Neuausgabe 2009 der Bibliographie zur Landschaft zwischen Diemel und Schleuse, Borkener Senke und Rhume. Band 2: Verzeichnis nach Sachgebieten. Universitätsverlag Göttingen, pdf.

Hutton J., 1788, Theory of the Earth, or investigation of the laws observable in the composition, dissolution, and restoration of land upon the Globe. "Transactions of the Royal Society of Edinburgh" Vol. 1, Part II, pp. 209-304, plates I and II; https:// web.archive.org/web/20030729055405/http:/ www.uwmc.uwc.edu/geography/Hutton/Hutton.htm (access 06.04.2018).

Hutton J., 1795, Theory of the Earth with proofs and illustrations. Edinburgh, Vol.1, plates III and IV; http://www.gutenberg.org/files/12861/12861-h/ 12861-h.htm (access 06.04.2018).

Jameson R., 1811, On colouring geognostical maps. In: Memoirs of the Wernerian Natural History Society for 1808-1810, Vol. 1, pp. 149-161, Edinburgh.

Johnston A.K., 1856, The physical atlas of natural phenomena. Edinburgh and London: William Blackwood and Sons.

Keferstein Ch., 1821, Teutschland geognostisch geologisch dargestellt und mit Charten und Durchschnittszeichnungen erläutert. Weimar: Landes-Industrie-Comptoirs.

Keferstein Ch., 1840, Geschichte und Litteratur der Geognosie, ein Versuch von... Halle: bei Johann Friedrich Lippert.

Książkiewicz A., 2016, Unifying prospects: tinting geological maps in nineteenth-century Britain. "Cartographica" Vol. 51, issue 3, pp. 159-174.

Lyell Ch., 1830-1833, Principles of geology being an attempt to explain the former changes of the Earth's surface by reference to causes now in operation, 2 vols., London: John Murray.

Mather J.D., 2016, Geology and landscape in SW England in the late eighteenth century, as recorded in the travel journals of William George Maton (1774-1840). In: Appreciating Physical Landscapes, Three Hundred Years of Geotourism, Geological Society of London, Special Publications) vol. 417. DOI: https://doi.org/10.1144/SP417.8 (Published: January 01, 2016). http://sp.lyellcollection.org/ content/417/1/171 (access 25.04.2018); GOOGLE e-book, pp. 171-185.

Maton W.G., 1797, Observations Relative Chiefly to the Natural History, Picturesque Scenery, and Antiquities, of the Western Counties of England, Made in the Years 1794 and 1796: Illustrated by a Mineralogical Map, and Sixteen Views in Aquatinta by Alken, vol. 2, Salisbury. DOI: https://archive. org/details/b24975515.

Medioni R., 2009, Les cartes géologiques en France: une aventure de plus de deux siec les. In: L'essor de la géologie française. Essais. Ed. Jean Gaudant, Paris: Mines ParisTech les Presses, pp. 201-224. Oldroyd D., 2013, Maps as pictures or diagrams: The early development of geological maps. In: Rethinking the fabric of geology. Ed. V.R. Baker, "Geological Society of America Special Paper" No. 502, pp. 41-101. DOI: https://doi.org/10.1130/SPE502.

Playfair J., 1802, Ilustrations of the Huttonian Theory of the Earth. Edinburgh: Printed for Cadell and Davies, and William Creech.

"Proceedings of the Geological Society of London, November 1838 to June 1842", 1842, Vol. 3, London: Printed by R. \& J.E. Taylor.

Robinson A.H., 1982, Early thematic mapping in the history of cartography. Chicago \& London: University of Chicago Press.

Savaton P., 1998, Le savoir savant de référence: étude descriptive des cartes géologiques depuis le debut du XIX siècle. In: La carte géologique dans l'enseignement secondaire. Bilan historique et didactique, réflexion et propositions d'apprentissages. Paris: Université Paris.

Smith W., 1815, A memoir to the map and delineation of the strata of England and Wales with part of Scotland. London: Printed for John Cary.

Smith W., 1817, Stratigraphical system of organized fossils, with reference to the specimens of the original geological collection in the British Museum, explaining their state of preservation and their use in identifying the British strata. London: Printed for E. Williams.

Szaniawska L., 2017, Geological content on maps and in texts accompanying them developed until the end of the 18th century. "Polish Cartographical Review" Vol. 49, no. 2, pp. 79-91.

Werner A.G., 1774, Von den äußerlichen Kennzeichen der Foßilien. Leipzig: bey Siegfried Lebrecht Crusius.

Werner A.G., 1787, Kurze Klassifikation und Beschreibung der verschiedenen Gebirgsarten. Dresden: Waltherischen Buchhandlung.

Werner A.G., 1791, Neue Theorie von der Entstehung der Gänge mit Anwendung auf den Bergau, besonders den freibergischen. Freiberg: Grelachische Buchdrukkerei.

Wołkowicz S., 2016, Ewolucja map geologicznych Dolnego Śląska na przykładzie bloku Karkonosko-lzerskiego. „Biuletyn Państwowego Instytutu Geologicznego" Nr 446, pp. 361-376.

Wołkowicz S., Wołkowicz K., 2014, Geological cartography in Poland in the 19th century. "Geological Quarterly" Vol. 58, no. 3, pp. 623-658.

Wójcik A.J., 2012, Ewolucja europejskiej kartografii geologicznej do początków XX w. "Analecta" Vol. 1-2, pp. 173-202.

Wójcik A.J., 2013, Carta Geologica. Mapy geologiczne Królestwa Polskiego wydane w latach 1815-1915. Katalog. Dąbrowa Górnicza. 
Wójcik Z., 1990, Najstarszy okres kartografii geologicznej Sudetów. "Annales Silesiae" Vol. 20, pp. 101-108.

\section{Internet sources}

Deutsche Fotothek (Bidok): Urheber Metadaten: http:// www.deutschefotothek.de/documents/obj/80809371. From the collection of Sächsische Landesbibliothek Staats- und Universitätsbibliothek Dresden (SLUB), Signatur/Inventar-Nr.: Hist.Sax.A.142 (access 14.06.2018).

Gallica: http://gallica.bnf.fr/ark:/12148/btv1b85922693/ f1.item. Map in the collection of Bibliothèque nationale de France, département Cartes et plans, GE DD-2987 (178) (access 14.06.2018).
Geological Society of London, General Map of Strata found in England \& Wales, 1801: https://www. geolsoc.org.uk/Library-and-Information-Services/ Exhibitions/William-Strata-Smith/The-Map/GeneralMap-of-Strata-found-in-England-and-Wales-1801: https://www.geolsoc.org.uk/Library-and-Information-Services/Exhibitions/William-Strata-Smith..; Reconstruction of William Smith's Geological Map of Bath (1799) https://www.flickr.com/photos/geologicalsocietylibrary/15796985838/ (access 14.06.2018). Norton M. Dorset Geology created 22 July 2012: https:// en.wikipedia.org/wiki/Dorset (access 19.06.2018). From the collection of Zentralbibliothek Zürich: http:// www.e-rara.ch/zuz/content/titleinfo/10712205 (access 14.06.2018). 